\title{
The holoplankton of the Santa Catarina coast, southern Brazil
}

\author{
CHARRID RESGALLA Jr. \\ Centro de Ciências Tecnológicas da Terra e do Mar/CTTMar, Universidade do Vale do Itajaí/UNIVALI \\ Rua Uruguai, 458, Caixa Postal 360, 88302-202 Itajaí, SC, Brasil \\ Manuscript received on November 19, 2009; accepted for publication on September 13, 2010
}

\begin{abstract}
This paper presents information from different sampling surveys carried out along the Santa Catarina coast in order to outline the biogeographical characteristics of the zooplankton in this region and identify species or groups of species with potential use as bioindicators. Based on a checklist of species of the zooplankton community in the state, it was observed that, in the warmer months of the year, the fauna is similar to that of the states of Paraná and São Paulo (e.g. Creseis virgula f. virgula, Penilia avirostris; Acartia lilljeborgi and Oithona oswaldocruzi), while in the colder months there are coastal representatives of the fauna of Rio Grande do Sul (e.g. Acartia tonsa). However, the zooplankton consists predominantly of warm water species for most of the year, which is typical of Tropical Shelf Waters. Various species of zooplankton can be used as hydrological indicators, enabling a distinction to be made between coastal waters which are influenced by continental inputs (e.g. Paracalanus quasimodo and Parvocalanus crassirostris), common in the north of the state, and processes of upwelling (e.g. Podon intermedius) and the influence of the Subtropical Shelf Front (e.g. Pleopis polyphemoides), coming from the south. The different environments investigated present a zooplankton abundance that depends on the influence of continental inputs and the possibility of their retaining and contribution for the coastal enrichment, which varies seasonally.
\end{abstract}

Key words: bioindicators, checklist, coastal species, water mass, coastal environments, biogeography.

\section{INTRODUCTION}

Zooplankton comprises groups of organisms commonly used as biological indicators, due to its short life cycle, high sensitivity, and abundance in aquatic ecosystems (Omori and Ikeda 1984). The knowledge on this community is vitally important in any type of environmental impact study for the installation and operation of enterprises in the coastal zone. Some zooplanktonic organisms are considered good hydrological indicators (Boltovskoy 1981), enabling the identification of different sources of water inputs that comprise the dynamic of an area.

In ecological terms, the knowledge on the zooplankton community provides information about the trophic situation of the system based on the characterization of the size structure of its constituents, as well

E-mail: cresgalla@univali.br as the feeding habits of different dominant species in the community (Parsons et al. 1984). Besides its importance in the pelagic trophic chain as a point of connection between the primary producers and the higher levels, this community presents many larvae of important fishing resources of commercial interest, such as crustaceans, decapods, molluscs and fish.

There is a lack of information concerning the zooplankton community of the Santa Catarina coast, which has been highlighted in major review works on the subject presented by Valentin et al. (1994), Brandini et al. (1997) and Lopes (2007). This lack of information is reinforced by the lack of access to data published in scientific congresses, or data generated by large oceanographic campaigns that include the continental shelf of this state. However, disperse information, both published and unpublished, can enable conclusions to be 
drawn on the biogeographical characteristics of the Santa Catarina coast, compared with other areas that have been more exhaustively investigated to the north and south of the state, such as São Paulo, Paraná and Rio Grande do Sul.

Therefore, drawing up a checklist of species recorded in a region enables, among other things, the establishment of the limits of geographical distribution of the species, comparison and confirmation of the existence of similarities among coastal regions, evaluation of the existence of species that indicate impacts and oceanographic conditions, and the establishment of key species in the use of monitoring of large-scale alterations, invasive species and test organisms applied to ecotoxicology.

\section{STUDY AREA}

The continental shelf of the state of Santa Catarina is located mainly within the Southeast Brazilian Continental Shelf (northern portion), though part of it lies on the Southern Brazilian Continental Shelf (southern portion), with its dividing point occurring at Santa Marta Cape (Hille et al. 2008) (Fig. 1).

The hydrological conditions of the Santa Catarina coast have been studied by Carvalho et al. (1998) and Hille et al. (2008), who highlight that the north coast is heavily influenced by continental inputs. On the south coast of the state, the phenomena of upwelling in summer and the influence of the plume from the Plata River and Sub-Antarctic Water (Subtropical Shelf Front) in winter (Piola et al. 2000) are key oceanographic processes that occur at Santa Marta Grande Cape. According to B.M. Castro Filho, unpublished data, Miranda (1982), Piola et al. (2000, 2005), Schettini et al. (2005) and Hille et al. (2008), the water masses occurring on the shelf are the Tropical Water (TW) of the Brazilian Current, with temperatures over $20^{\circ} \mathrm{C}$ and salinity higher than 36.4, and the South Atlantic Central Water (SACW), characterized by temperatures below $20^{\circ} \mathrm{C}$ and salinity ranging from 36.4 to 34.5 . The latter lies at greater depths and is responsible for strong thermal gradients in the water column, indicating processes of upwelling on the continental shelf (Miranda 1982).

The Coastal or Shelf Water is the result of continental inputs on the TW and SACW. Finally, the Sub-
Antarctic Shelf Water, which originates from the mixing of the Malvinas Current with the discharge from the Prata River and Patos Lagoon, borders the south coast of Brazil as far as the region of Santa Marta Grande Cape in winter (Piola et al. 2000).

The north of Santa Catarina is influenced by various river systems, which change the concentrations of nutrients and the biological processes. These include the Itapocu, Itajaí-açu, Tijucas and Tubarão Rivers. In general, a decrease in salinity and an increase in concentrations of surface nutrients are seen in the areas around the river mouths of these systems (Bellotto et al. 1996, Schettini et al. 1998). The continental inputs, indented geography, and presence of numerous islands, together make up a coastline with various sub-environments, each of which has its own oceanographic features and biological species.

The environments for which more technical and scientific information have been gathered in recent years are shown in Figure 1 and Table I, and are mainly located to the north of the state of Santa Catarina:

1) The Babitonga Bay, on the north coast of Santa Catarina, is an environment which is characterized by an extensive formation of mangroves with continental inputs from three main rivers: The Palmital, the Cubatão and the Cachoeira Rivers (Kuroshima and Bellotto 1998, Cunha et al. 1999).

2) The Armação do Itapocoroy Bay, has been the object of intensive studies in recent years, as it is currently the largest mussel cultivation area in the state. According to Schettini et al. (1999), the waters of the Armação do Itapocoroy Bay are typically comprised of coastal waters (salinity lower than 34), with a seasonal temperature ranging from $19^{\circ} \mathrm{C}$ to $28^{\circ} \mathrm{C}$. Both the salinity and the load of material in suspension are directly influenced by the Itajaí-açu River (Carvalho et al. 1998, Resgalla Jr and Schettini 2006), which has a plume of brackish water flowing northwards from the river mouth.

3) Navegantes Beach - a dissipative beach, heavily influenced by the inputs from the Itajaí-açu River mouth (Rörig et al. 1997).

4) Itajaí-açu River estuary and adjacent coastal region - the Itajaí-açu River basin is the largest river basin, 


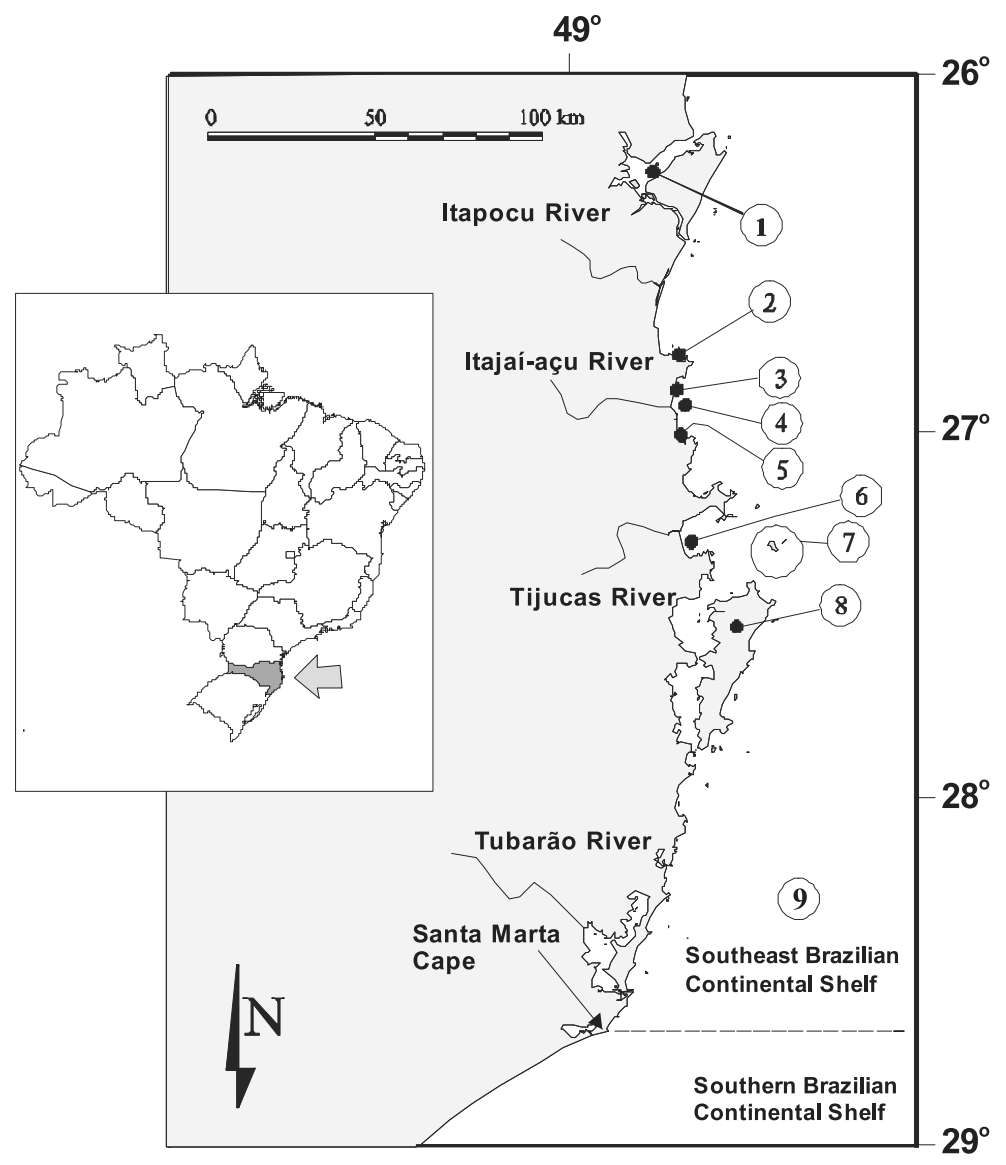

Fig. 1 - Location of the state of Santa Catarina $\left(25^{\circ} 57^{\prime} 41^{\prime \prime}-29^{\circ} 23^{\prime} 55^{\prime \prime} \mathrm{S}\right.$ and $\left.48^{\circ} 19^{\prime} 37^{\prime \prime}-53^{\circ} 50^{\prime} 00^{\prime \prime} \mathrm{W}\right)$ in the south of Brazil, and coastal environments in which the samplings of zooplankton were collected (Table I). It also shows the identification of the rivers, and division of the continental shelf at Santa Marta Cape.

with $15,111 \mathrm{~km}^{2}$, which corresponds to $25 \%$ of the total area of the state. The influence of salinity, which characterizes the estuary itself, is observed $30 \mathrm{Km}$ upstream from the river mouth due to the amplitude of the spring tide of $1.2 \mathrm{~m}$ and the pluviometric regimes (Schettini et al. 1998, Rörig 2005).

5) The Camboriú Bay highlights the influence of the Camboriú River on the salinity of the waters in the southern portion (F. Morelli, unpublished data, Schettini and Carvalho 1998).

6) The Zimbros Bay is influenced by the action of waves and by an extensive sedimentary plain, produced by inputs from the Tijucas River (Schettini and Carvalho 1998).

7) The Arvoredo Marine Biological Reserve is located $11 \mathrm{~km}$ to the north of Santa Catarina Island (Flo- rianópolis), and is comprised of four islands influenced by the Brazilian Current and the Subtropical Shelf Front. It is characterized by a diversity of transitional areas (Rocha et al. 2005).

8) Santa Catarina Island, in the municipality of Florianópolis, has various environments that have been historically sampled in relation to their plankton community, particularly Conceição Lagoon, an estuarine environment whose studies date back to 1982 (Knoppers et al. 1984, Odebrecht 1988).

9) Unpublished records of zooplankton species occurring in the beaches to the south of the state (municipality of Garopaba), as well as samplings in oil drilling platforms, also make up the sampling grid for the Santa Catarina external continental shelf and oceanic area. 
TABLE I

Identification of the samplings carried out on the Santa Catarina coast by environment (according to Fig. 1), type of study, number of samples and collection date.

\begin{tabular}{|c|c|c|c|c|}
\hline Area & Environment & Study & $\begin{array}{l}\text { Number of } \\
\text { samples }\end{array}$ & Date \\
\hline \multirow{4}{*}{1} & \multirow{4}{*}{ Babitonga Bay } & Schettini et al. (2002) & 10 & 03/1999 \\
\hline & & Schettini et al. (2002) & 02 & $11 / 2000$ \\
\hline & & This paper & 07 & $03 / 2006$ \\
\hline & & This paper & 42 & $09 / 2006-07 / 2007$ \\
\hline 2 & Itapocoroy Bay & $\begin{array}{l}\text { Resgalla Jr and } \\
\text { Veado (2006), } \\
\text { R.D. Nunes, } \\
\text { unpublished data }\end{array}$ & 120 & $09 / 2002-09 / 2003$ \\
\hline 3 & Navegantes Beach & Rörig et al. (1997) & 02 & $10 / 1995$ \\
\hline \multirow{5}{*}{4} & \multirow{5}{*}{$\begin{array}{l}\text { Itajaí-açu River and the } \\
\text { adjacent coastal region }\end{array}$} & $\begin{array}{l}\text { Schettini et al. (1998), } \\
\text { Rörig et al. (2003) }\end{array}$ & 11 & 03/1996 \\
\hline & & Resgalla Jr et al. (2008) & 126 & $11 / 2002-12 / 2003$ \\
\hline & & $\begin{array}{l}\text { L.D.V. Veado, } \\
\text { unpublished data }\end{array}$ & 45 & $12 / 2005-05 / 2007$ \\
\hline & & This paper & 14 & $12 / 2003$ \\
\hline & & $\begin{array}{l}\text { L.D.V. Veado, } \\
\text { unpublished data }\end{array}$ & 95 & $06 / 2005-01 / 2007$ \\
\hline 5 & Balneário Camboriú Bay & This paper & 10 & $04 / 2007$ \\
\hline 6 & Zimbros Bay & This paper & 32 & $02 / 2007,03 / 2007$ and $07 / 2007$ \\
\hline \multirow[t]{2}{*}{7} & \multirow{2}{*}{$\begin{array}{l}\text { Arvoredo Marine } \\
\text { Biological Reserve }\end{array}$} & $\begin{array}{l}\text { L.M. Fernandes, } \\
\text { unpublished data }\end{array}$ & 15 & $11 / 1995$ \\
\hline & & Resgalla Jr et al. (2004) & 12 & $12 / 1998$ \\
\hline \multirow[t]{2}{*}{8} & \multirow[t]{2}{*}{ Santa Catarina Island } & $\begin{array}{l}\text { Resgalla Jr (2001), } \\
\text { Veado and Resgalla Jr } \\
\text { (2005), D.C. Mori, } \\
\text { unpublished data }\end{array}$ & 150 & $10 / 1996-10 / 2006$ \\
\hline & & This paper & 24 & $02 / 2007,03 / 2007$ and $07 / 2007$ \\
\hline \multirow[t]{2}{*}{9} & \multirow{2}{*}{$\begin{array}{l}\text { Oceanic region } \\
\text { South of the state }\end{array}$} & This paper & 06 & $03 / 2003$ and $06 / 2003$ \\
\hline & & This paper & 03 & $04 / 1997$ and 2003 \\
\hline
\end{tabular}

\section{METHODOLOGY}

Data were compiled on the density and specific composition of the zooplankton community and obtained in different coastal environments of the Santa Catarina coast and in different seasons of the year using different sampling equipment, but always in quantitative samplings. The samplings in estuaries and bays were carried out using WP-2 nets with a $200 \mu \mathrm{m}$ mesh size and $30 \mathrm{~cm}$ opening diameter. For the beach sampling, conical nets were used, with a $300 \mu \mathrm{m}$ mesh size and $50 \mathrm{~cm}$ opening diameter, and for shelf areas the standard WP-2 net was used, with a $200 \mu \mathrm{m}$ mesh size and $60 \mathrm{~cm}$ opening diam- eter. All the trawls were carried out using a flowmeter to estimate the volume of filtered water. Abiotic data for water temperature and salinity were obtained in all samplings. Information from the samples is presented in Table I and summarized for each environment.

Besides the new data for zooplankton, the publications used in this work referring to the coastal region were as follows: Schettini et al. (2002) to the Babitonga Bay; Duarte (1999), Resgalla Jr and Veado (2006) and R.D. Nunes, unpublished data to the Armação do Itapocoroy Bay; Rörig et al. (1997) to Navegantes Beach; Schettini et al. (1998, 2005), Rörig et al. (2003), Resgalla Jr et al. (2008) and L.D.V. Veado, unpublished 
data to the Itajaí-açu River estuary and adjacent coastal region; M.J. Novaes, unpublished data to Camboriú Bay; L.M. Fernandes, unpublished data and Resgalla Jr et al. (2004) to the Arvoredo Marine Biological Reserve; and Resgalla Jr (2001), Veado and Resgalla Jr (2005) and D.C. Mori unpublished data to the South Bay (Santa Catarina Island).

For the area of the external shelf, there are works on zooplankton groups carried out based on samples of major scientific cruises, such as the Projeto Uso e Exploração Racional do Ambiente Marinho (Rational Use and Exploitation of the Marine Environment) $\left(24^{\circ}-29^{\circ} \mathrm{S}\right)$ carried out in 1976 (M.R. Oliveira, unpublished data), CONVERSUT - Estudo da Área de Convergência Sub-tropical (Study of the Sub-tropical Area of Convergence) $\left(28^{\circ}-34^{\circ} \mathrm{S}\right)$ carried out from 1977 to 1981 (M.J. Coelho, unpublished data), SUESTE I $\left(24^{\circ}-29^{\circ} \mathrm{S}\right)$ carried out in 1982 (W.J.A. Amaral, unpublished data), SARP - Sardine/Anchovy Recruitment Project $\left(28^{\circ} \mathrm{S}\right)$ carried out in 1989 , Projeto Sardinha 2 $\left(23^{\circ}-28^{\circ} \mathrm{S}\right)$ carried out in 1993 (Campos 2004), and ECOSAR 2 - Prospecção e Avaliação de Biomassa do Estoque de Sardinha, na Costa Sudeste, por Métodos Hidroacústicos (Prospecting and Evaluation of the Sardine Stock Biomass on the Southeast Coast, by Hydroacoustic Methods) $\left(22^{\circ}-28^{\circ} \mathrm{S}\right)$ carried out in 1995 (E. Muxagata, unpublished data).

Additional information for Cnidaria was obtained in the works of Resgalla Jr et al. (2005) and Rossetto et al. (2007) relating to records of jellyfish accidents on the main beaches of the state.

A checklist of zooplankton species was drawn up, and comparisons were made with the fauna of the coastal environments to the north, São Paulo (C.L. De La Rocha, unpublished data) and Paraná (Montú 1987, Montú and Cordeiro 1988), and to the south, in Rio Grande do Sul (Montú 1980, Montú and Gloeden 1986, E. Muxagata, unpublished data), in order to determine the limits of distribution of species and establish the similarity between the areas. The compilation works of the plankton community for the Brazilian coast, carried out by Boltovskoy (1981, 1999), Valentin et al. (1994), Brandini et al. (1997), Lopes et al. (2006) and Lopes (2007), were used to help to determine the similarities observed.
The check list for this work did not include the meroplankton occurring on the Santa Catarina coast, which can be obtained in works with the larvae of Cirripedia, by Severino and Resgalla Jr (2005), larvae of Decapoda, by Koettker and Freire (2006), and various works with ictioplankton (M.D.P. Costa, unpublished data, Souza-Conceição 2008, Macedo-Soares et al. 2009, T. Rutkowski, unpublished data, T. Rutkowski, unpublished data). A complete list of freshwater zooplankton species occurring in the estuary of the Itajaíaçu River can be seen in L.D.V. Veado unpublished data.

For the classification of species by type of water of occurrence, TS-P (Temperature, Salinity and Plankton) diagrams were created for the main coastal environments of Santa Catarina involving all the sampling periods and the records of species observed, thereby delimiting the representative groups of the coastal and oceanic areas, as well as the warm and cold waters.

\section{RESULTS AND DISCUSSION}

The marine zooplankton of the Santa Catarina coast is highly diverse, comprising 21 main groups and 150 taxa distributed by family, genus, species and stages of development (Table II). Copepoda had the highest taxonomic diversity, which was represented by 52 taxa on this coast.

\section{DOMINANT ENVIRONMENTS AND SPECIES}

For the external continental shelf region, the zooplankton community is highly diverse. However, this diversity is less than that observed by M.J. Coelho, unpublished data and Resgalla Jr and Montú (1995) for Chaetognatha, suggesting a predominance of the Tropical Water from the Brazilian Current, with salinities higher than 33 and temperatures higher than $20^{\circ} \mathrm{C}$, and a certain distance from the western border of the Subtropical Convergence Zone. This characteristic is confirmed by the predominance of species like the Copepoda Acartia negligens, the Cladocera Evadne spinifera, and the Chaetognatha Sagitta serratodentata. Despite the presence of oceanic representatives of warm waters, coastal species typical of salinities lower than 31, such as Acartia lilljeborgi and Penilia avirostris, are common on the external shelf, but in low densities (Fig. 2).

For the coastal zone, the zooplankton is dominated by Copepoda, the most representative of the group 
TABLE II

Taxa of zooplankton identified in different areas (according to the caption of Fig. 1) of the Santa Catarina coast.

\begin{tabular}{|c|c|c|c|}
\hline Groups/Species & Environment & Groups/Species & Environment \\
\hline Cnidaria & & Copepoda & \\
\hline Polyps & 4,8 & Limnic copepoda & 1,4 \\
\hline Hidromedusae & $1,3,4,8,9$ & Acartia lilljeborgi Giesbrecht, 1889 & $1,2,3,4,8$ \\
\hline Liriope tetraphylla (Chamisso and Eysenhardt, 1821) & 4,8 & Acartia negligens Dana, 1849 & 9 \\
\hline Calicophorae & $3,4,8,9$ & Acartia $\mathrm{sp}$ & 8,9 \\
\hline Physalia physalis (Linnaeus, 1758) & $2,7,9$ & Acartia tonsa Dana, 1849 & 1,8 \\
\hline Semaeostomeae & $1,2,5,9$ & Calanidae & $4,8,9$ \\
\hline Cubozoa & 2 & Calanopia americana Dahl, 1894 & 8 \\
\hline Linuche unguiculata (Schwartz, 1788) & 5 & Calocalanidae & 4 \\
\hline Chiropsalmus quadrumanus (Müller, 1859) & 2 & Calocalanus sp & 8,9 \\
\hline Olindias sambaquiensis Muller, 1861 & 9 & Centropages velificatus (Oliveira, 1947) & 4,8 \\
\hline Lychnorhiza lucerna Haeckel, 1880 & 9 & Centropagidae & 9 \\
\hline Tamoya haplonema (Müller, 1859) & 2 & Clytemnestra rostrata (Brady, 1883) & 4,9 \\
\hline \multirow[t]{3}{*}{ Pelagia noctiluca (Forsskal, 1775) } & 9 & Copilia mirabilis Dana, 1852 & 9 \\
\hline & & Corycaeus sp & $3,4,8,9$ \\
\hline & & Corycaeus speciosus Dana, 1849 & 9 \\
\hline Ctenophorae & & Eucalanus cornutus Sars, 1912 & 9 \\
\hline \multirow[t]{2}{*}{ Beroe sp } & 1,8 & Eucalanus crassus Giesbrecht, 1888 & 9 \\
\hline & & Eucalanus pileatus Giesbrecht, 1888 & 4,8 \\
\hline Mollusca & & Eucalanus sewelli Dana, 1849 & 9 \\
\hline Bivalvia (veliger) & $4,8,9$ & Eucalanus sp & 9 \\
\hline Gastropoda (veliger) & $1,4,8,9$ & Euterpina acutifrons (Brian, 1921) & $1,4,8$ \\
\hline Creseis virgula f. virgula (Rang, 1828) & $4,8,9$ & Farranula gracilis (Dana, 1849) & 9 \\
\hline Limacina $\mathrm{sp}$ & 4 & Farranulla $\mathrm{sp}$ & 4,9 \\
\hline Limacina inflata (d'Orbigny, 1836) & 4,9 & Hemicyclops thalassius Vervoort and Ramires, 1966 & 8 \\
\hline Limacina trochiformis (d'Orbigny, 1836) & 8,9 & Labidocera fluviatilis Dahl, 1894 & 1,4 \\
\hline Janthina $\mathrm{sp}$ & 2 & Macrosetella gracilis (Dana, 1847) & $4,8,9$ \\
\hline Atlanta $\mathrm{sp}$ & 8,9 & Mesocyclops sp & 1 \\
\hline Pterotracheidae & 9 & Microsetella rosea (Dana, 1849) & 9 \\
\hline \multirow[t]{3}{*}{ Cavolinia inflexa f. imitans (Pfeffer, 1880) } & 9 & Monstrilla rogusa Davis, 1947 & 2 \\
\hline & & Monstrilla $\mathrm{sp}$ & 2 \\
\hline & & Monstrilloida & 2,8 \\
\hline Annelida & & Oithona oswaldocruzi Oliveira, 1947 & $1,4,8$ \\
\hline Oligochaeta & 1 & Oithona ovalis Herbst, 1955 & 4 \\
\hline Polychaeta (larvae & $1,4,8$ & Oithona plumifera Baird, 1843 & $3,4,8$ \\
\hline \multirow[t]{2}{*}{ Polychaeta (planktonic) } & 8 & Oithona $\mathrm{sp}$ & $4,8,9$ \\
\hline & & Oncaea $\mathrm{sp}$ & 4,9 \\
\hline Cladocera & & Oncaea venusta Philippi, 1843 & 8 \\
\hline Diaphanosoma sp & 1 & Paracalanus nanus (Sars, 1907) & 8 \\
\hline Ilyocryptus spiniger Herrick, 1884 & 1,4 & Paracalanus quasimodo Bowman, 1971 & 8 \\
\hline Moina minuta Hansen, 1899 & 1,4 & Paracalanus sp & $1,3,4,8,9$ \\
\hline Daphinia $\mathrm{sp}$ & 1 & Parvocalanus crassirostris (Dahl, 1894) & 8 \\
\hline Ceriodaphinia $\mathrm{sp}$ & 1 & Phaenna spinifera Claus, 1863 & 8,9 \\
\hline Penilia avirostris Dana, 1852 & $3,4,7,8,9$ & Pontellidae & $4,8,9$ \\
\hline Pseudevadne tergestina (Claus, 1877) & $3,4,7,8,9$ & Pseudocalanidade & 3,4 \\
\hline Evadne spinifera Müller, 1868 & $1,4,7,9$ & Pseudodiaptomus richardi (Dahl, 1894) & $1,3,4,8$ \\
\hline Pleopis polyphemoides (Leuckart,1859) & $2,4,8$ & Rhincalanus nasutus Giesbrecht 1888 & 9 \\
\hline Pleopis schmackeri (Poppe, 1889) & 4,7 & Sapphirina stellata Giesbrecht, 1891 & 9 \\
\hline \multirow[t]{3}{*}{ Podon intermedius Lilljeborg, 1853} & 4,7 & Scolecithricidae & 9 \\
\hline & & Temora $\mathrm{sp}$ & $1,4,8,9$ \\
\hline & & Temora stylifera (Dana, 1849) & $3,4,8$ \\
\hline Ostracoda & & Temora turbinata (Dana, 1849) & 4,8 \\
\hline Benthonic & $8,4,3$ & Thaumaleus longispinosum (Bourne, 1890) & 2 \\
\hline Planktonic & 9 & Thaumaleus sp (Monstrilloida) & 2 \\
\hline
\end{tabular}


TABLE II (continuation)

\begin{tabular}{|c|c|c|c|}
\hline Groups/Species & Environment & Groups/Species & Environment \\
\hline Cirripedia & & Chaetognatha & \\
\hline Nauplii & $1,2,3,4,8$ & Sagitta $\mathrm{sp}$ & 8,9 \\
\hline \multirow[t]{2}{*}{ Cypris } & $1,2,4,8$ & Krohnitta pacifica (Aida, 1897) & 4,7 \\
\hline & & Krohnitta subtilis (Grassi, 1881) & 9 \\
\hline \multirow[t]{2}{*}{ Stomatopoda (larvae) } & 7,8 & Pterosagitta draco (Krohn, 1853) & 9 \\
\hline & & Sagitta enflata Grassi, 1881 & $3,4,7,8,9$ \\
\hline Mysida & & Sagitta hexaptera d'Orbigny, 1843 & 9 \\
\hline Metamysidopsis elongata atlantica (Bacescu, 1968) & $3,5,8$ & Sagitta hispida Conant, 1895 & $4,7,8$ \\
\hline \multirow[t]{2}{*}{ Promysis atlantica Tattersall, 1923} & 7,8 & Sagitta minima Grassi, 1881 & 9 \\
\hline & & Sagitta serratodentata Krohn, 1853 & 9 \\
\hline Isopoda & $1,3,8,9$ & Sagitta friderici (=tenuis) (Ritter-Zahony, 1911) & $1,4,7,8,9$ \\
\hline Amphipoda & & Larvacea & \\
\hline Caprellidae & 8 & Oikopleura sp & $3,4,8$ \\
\hline Gammaridea & $3,4,8$ & Oikopleura dioica (Fol, 1872) & 1,8 \\
\hline \multirow[t]{3}{*}{ Hiperiidea } & $4,8,9$ & Oikopleura parva Lohmann, 1896 & 8 \\
\hline & & Oikopleura intermedia Lohmann, 1896 & 9 \\
\hline & & Oikopleura fusiformis Fol, 1872 & 9 \\
\hline Euphausiacea & & Oikopleura longicauda (Vogt, 1854) & 9 \\
\hline Metanauplius & 9 & Oikopleura rufescens Fol, 1872 & 9 \\
\hline \multirow[t]{3}{*}{ Caliptopis } & $4,7,9$ & Oikopleura albicans (Leuckart, 1854) & 9 \\
\hline & & Oikopleura cornutogastra Aida, 1907 & 9 \\
\hline & & Fritillaria pellucida (Busch, 1851) & 9 \\
\hline Decapoda & & Fritillaria formica Fol, 1872 & 9 \\
\hline Egg & 8 & Fritillaria sargassi Lohmann, 1896 & 9 \\
\hline Nauplii & 8 & Fritillaria haplostoma Fol, 1872 & 9 \\
\hline Protozoea & $4,8,9$ & Fritillaria tenella Lohmann, 1896 & 9 \\
\hline Mysis & $1,4,8,9$ & Tectillaria fertilis (Lohmann, 1896) & 9 \\
\hline Zoea & $1,3,4,8,9$ & & \\
\hline Megalopa & $1,4,9$ & Ascidiacea & 8 \\
\hline Palinura (decapodito) & 8 & & \\
\hline Penaeus sp (decapodito) & 7,8 & Lophophorata & 8 \\
\hline Lucifer $\mathrm{sp}$ & 7,8 & & \\
\hline \multirow[t]{3}{*}{ Lucifer faxoni Borradaile, 1915} & $4,8,9$ & Thaliacea & \\
\hline & & Doliolum nationalis Borgert, 1894 & $4,7,9$ \\
\hline & & Thalia cicar van Soest, 1973 & 9 \\
\hline \multirow[t]{3}{*}{ Thanaidacea } & 1 & Thalia democratica (Forskal, 1775) & $2,4,7,9$ \\
\hline & & Thalia orientalis Tokioka, 1937 & 9 \\
\hline & & Pyrosoma atlanticum Péron, 1804 & 9 \\
\hline Echinodermata & & Salpa fusiformis (Cuvier, 1804) & 9 \\
\hline Pluteus & $3,4,8$ & Weelia cylindrica (Cuvier, 1804) & 4 \\
\hline
\end{tabular}

being Acartia lilljeborgi and Paracalanus quasimodo, followed by the genera Corycaeus and Temora. This prevalence is provided by waters with temperatures between $20^{\circ} \mathrm{C}$ and $29.6^{\circ} \mathrm{C}$, and salinities between 25 and 35 (Fig. 2). Other well-represented organisms are the Larvacean Oikopleura dioica, the Chaetognatha Sagitta friderici and Sagitta enflata and, in particular, the Cladocera Penilia avirostris and Evadne tergestina. These species are common in the Brazilian coast, and are typical of warm waters of the continental shelf under strong influence of Tropical Water of the Brazilian Current (Björnberg 1981, Ramirez 1981, Resgalla Jr and Montú 1993, 1995).

Estuarine zooplankton, typical of salinity between 5 and 30, is also dominated by Copepoda of the genus Acartia, presenting alternating prevalence between species of $A$. lilljeborgi and $A$. tonsa whose ecological preferences have been described by Björnberg (1981), i.e. $A$. lilljeborgi presents preferences for warmer waters (temperatures higher than $20^{\circ} \mathrm{C}$ ), while $A$. tonsa is common 
(1) Babitonga Bay
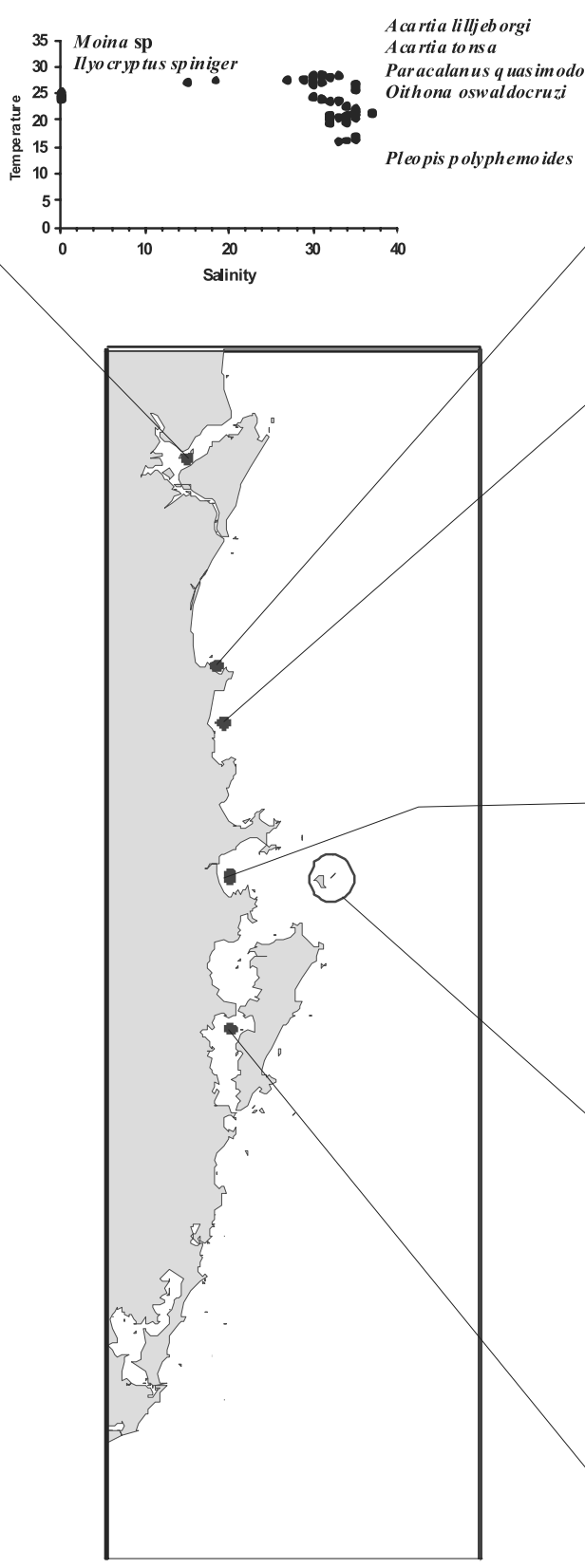

(2) Itapocoroy Bay

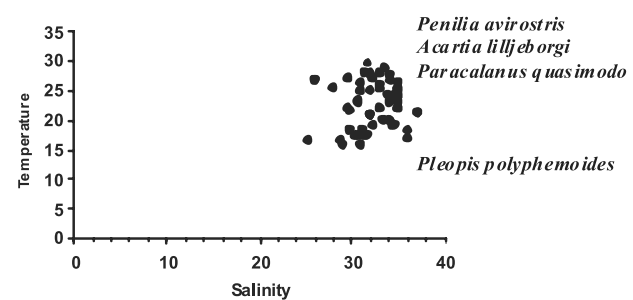

(4) Itajaí-açu River

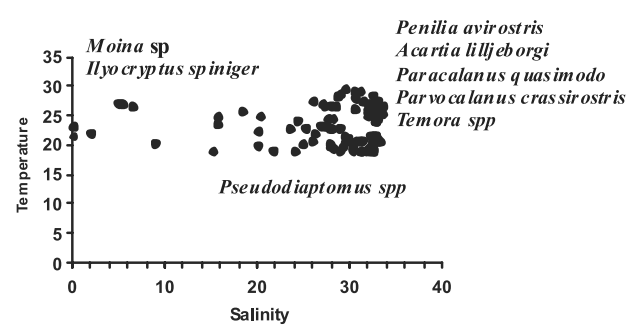

(6) Tijucas Bay

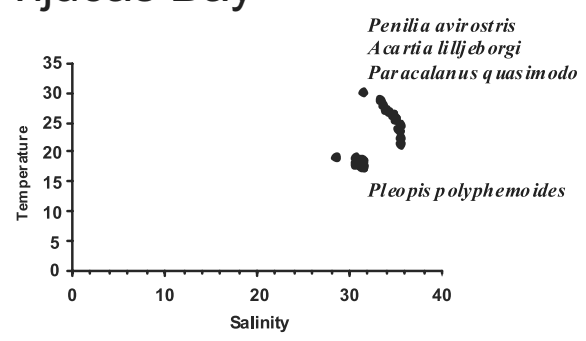

(7) Arvoredo Reserve

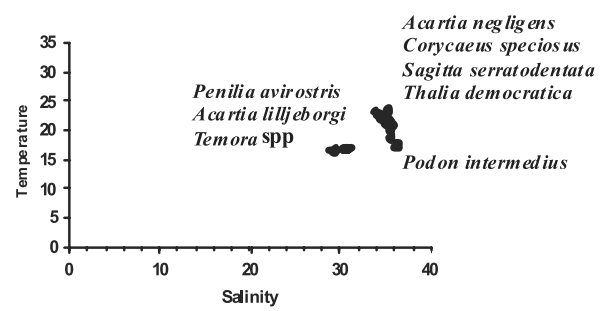

(8) South Bay

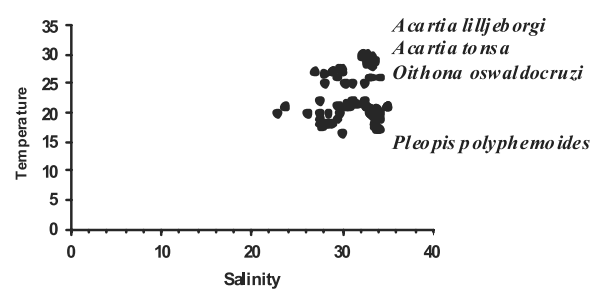

Fig. 2 - TS diagrams and main species of zooplankton organisms occurring on the Santa Catarina coast. The numbers refer to the environments described in Figure 1 and Table I. 
in colder waters (temperatures lower than $20^{\circ} \mathrm{C}$ ). In the north of the state, in the Babitonga Bay, A. lilljeborgi is dominant, while in the central region (the South Bay of Santa Catarina Island) and Conceição Lagoon (Odebrecht 1988), A. tonsa has higher densities during the spring and winter. It seems that the occurrence of $A$. tonsa depends not only on variations in salinity and temperature, but also on the characteristics of the environments covered and the availability of food in these environments (Paffenhoefer and Stearns 1988). This fact is corroborated by the absence of $A$. tonsa in the Itajaí-açu River estuary.

Other species of Copepoda also occur in significant quantities in the estuaries of Santa Catarina, including Oithona oswaldocruzi, Parvocalanus crassirostris, Paracalanus quasimodo, Temora stylifera, T. turbinata and Euterpina acutifrons, and the Chaetognath Sagitta friderici. The fauna of the estuarine zooplankton is very similar to that found in the estuaries of São Paulo, Paraná and Rio Grande do Sul (Table III). The difference lies in the occurrence and prevalence of species of Acartia, suggesting that the Santa Catarina coast is a transitional region between the fauna of the south (colder) and that of the north (warmer).

For the beach regions (Navegantes and Balneário Camboriú beaches), the similarity with the region of Rio Grande do Sul is due to the resident species of Mysidacea, which are typical of the surf zone of dissipative beaches comprised almost exclusively of Metamysidopsis elongata atlantica (Rörig et al. 1997, M.J. Novaes, unpublished data).

\section{ENVIRONMENTS AND TOTAL DENSITY OF ZOOPLANKTON}

In terms of density of zooplankton, the highest values are reported in estuarine environments or coastal zones close to or influenced by inputs from the rivers (Fig. 3). The freshwater input and its mixing within the Babitonga Bay favour a higher residence time of the waters and the development of the phytoplankton community and the herbivorous zooplankton in its environment. In the Armação do Itapocoroy Bay, despite it being a relatively exposed region, the influence of the Itajaí-açu River plume is responsible for the plankton development of the area through the input of nutrients for the phytoplankton (Resgalla Jr and Schettini 2006). In the South
Bay of the Santa Catarina Island, the lower dynamic of the waters and inputs from small rivers lead to the development of an abundant planktonic community.

\section{BIOMASS}

Data on zooplankton biomass are more limited for the area of study. For the adjacent coastal region of the mouth of the Itajaí-açu River, Schettini et al. (1998) observed a maximum of $46.92 \mathrm{mg} . \mathrm{m}^{-3}$ in dry mass and high organic carbon content, indicating high biological activity in the river plume. Data for biovolume and wet mass biomass were obtained from the Arvoredo Marine Biological Reserve, and indicated high values (maximum $0.51 \mathrm{~mL} . \mathrm{m}^{-3}$ and $8.23 \mathrm{~g} . \mathrm{m}^{-3}$ ) related to the occurrence of the Thaliacea Thalia democratica (L.M. Fernandes, unpublished data, Resgalla Jr et al. 2004).

\section{OUTBREAKs/BLOOMS}

Seasonally, high densities of Thalia democratica and the Eutecosomata Creseis virgula f. virgula occur, normally lasting from the end of summer until the autumn. These occurrences have been highlighted by other works, particularly for Thaliacea on the coast of São Paulo (Pires-Vanin et al. 1993), Santa Catarina (L.M. Fernandes, unpublished data) and from Rio de Janeiro to Rio Grande do Sul (W.J.A. Amaral, unpublished data), highlighting their relationships with locations with higher phytoplanktonic production that may be involved with processes of localized upwelling along the coast (Resgalla Jr et al. 2001). In the Arvoredo Marine Biological Reserve, the occurrence of a higher abundance of Thaliacea was also related to the variation in concentration of the ammonicacal nitrogen in the water column (Resgalla Jr et al. 2004). It is interesting to note that both Thaliacea and Pteropoda present the same feeding strategy, i.e. they capture their food by filtering the water through the mucus, which retains small particles. This strategy makes them more efficient than other filterers and gives advantages in short processes of upwelling. These processes favor the development of a microbial loop following the death of the phytoplankton after the nutrients have been exhausted. However, these alterations in the pelagic system have still been little studied for the Brazilian coast. 
TABLE III

Main representatives of the zooplankton community of different estuaries of the south and southeast regions of Brazil.

\begin{tabular}{|c|c|c|c|c|}
\hline Groups & $\begin{array}{l}\text { Cananéia Estuary } \\
\text { (SP) }\end{array}$ & $\begin{array}{l}\text { Paranaguá Bay } \\
\text { (PR) }\end{array}$ & $\begin{array}{c}\text { Babitonga Bay - Itajaí-açu River } \\
\text { - South Bay - Conceição Lagoon } \\
\text { (SC) }\end{array}$ & $\begin{array}{l}\text { Patos Lagoon Estuary } \\
\text { (RS) }\end{array}$ \\
\hline Copepoda & $\begin{array}{c}\text { Acartia lilljeborgi, } \\
\text { Oithona oswaldocruzi, } \\
\text { Pseudodiaptomus } \\
\text { richardi, Acartia tonsa, } \\
\text { Parvocalanus crassirostris }\end{array}$ & $\begin{array}{c}\text { Acartia lilljeborgi, } \\
\text { Euterpina acutifrons, } \\
\text { Oithona oswaldocruzi, } \\
\text { Paracalanus quasimodo, } \\
\text { Oithona ovalis }\end{array}$ & $\begin{array}{c}\text { Acartia lilljeborgi, Acartia tonsa, } \\
\text { Oithona oswaldocruzi, Euterpina } \\
\text { acutifrons, Temora stylifera, } \\
\text { Parvocalanus crassirostris, } \\
\text { Paracalanus quasimodo }\end{array}$ & $\begin{array}{c}\text { Acartia tonsa, } \\
\text { Acartia lilljeborgi, } \\
\text { Paracalanus quasimodo, } \\
\text { Parvocalanus crassirostris, } \\
\text { Euterpina acutifrons }\end{array}$ \\
\hline Myside & $\begin{array}{c}\text { Metamysisdopsis elongata } \\
\text { atlantica, Promysis } \\
\text { atlantica, Bwomaniella } \\
\text { brasiliensis }\end{array}$ & - & $\begin{array}{c}\text { Metamysisdopsis elongata } \\
\text { atlantica, Promysis atlantica }\end{array}$ & $\begin{array}{c}\text { Metamysisdopsis elongata } \\
\text { atlantica, Promysis } \\
\text { atlantica }\end{array}$ \\
\hline Chaetognatha & - & Sagitta friderici & Sagitta friderici & Sagitta friderici \\
\hline Larvacea & - & Oikopleura dioica & Oikopleura dioica & Oikopleura dioica \\
\hline Cladocera & - & Penilia avirostris & Penilia avirostris & - \\
\hline
\end{tabular}

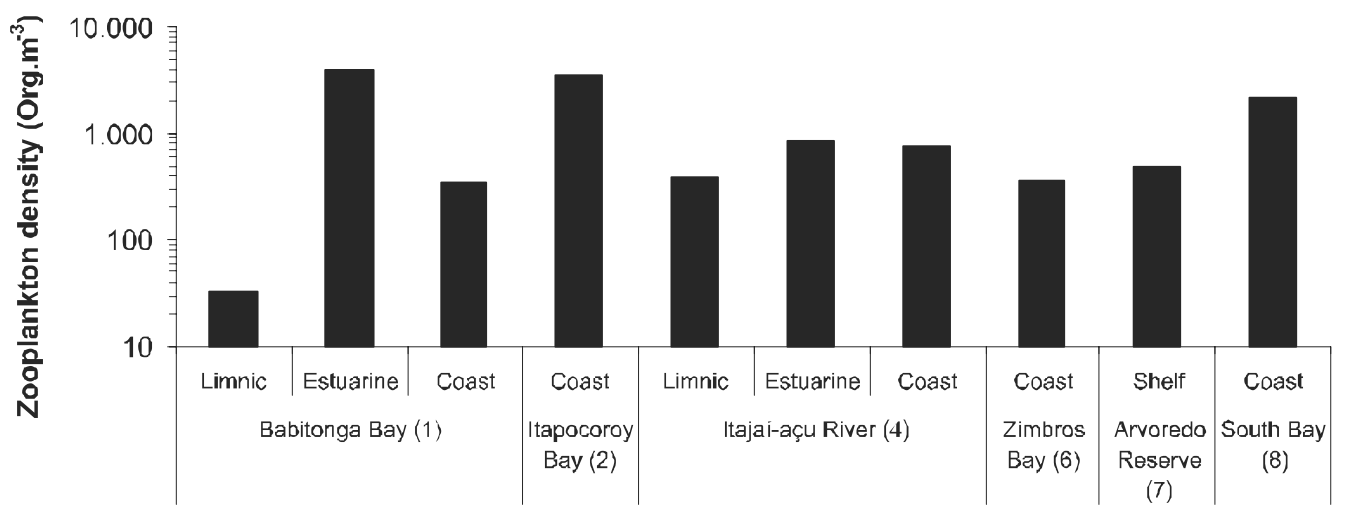

Site

Fig. 3 - Mean of the total values of all data available for the zooplankton densities (Org. $\left.\mathrm{m}^{-3}\right)$ in different environments and waters for the Santa Catarina coast.

\section{INDICATORS}

For other constituents of the shelf, the use of cladocera as a hydrological indicator is highlighted. Podon intermedius was characterized as an indicator of SACW upwelling on the continental shelf of Rio de Janeiro (Valentin 1988) and São Paulo (C.E.F. Rocha, unpublished data), and its occurrence in the region adjacent to the Itajaí-açu River mouth and the Arvoredo Marine Biological Reserve was also related to these oceanographic processes (Fernandes 1998, Schettini et al. 1998). Pleopsis polyphemoides has been highlighted as an indicator of the Subtropical Shelf Front (Sub-Antarctic Water under the influence of the Prata River) to Rio Grande do Sul (Resgalla Jr and Montú 1993) and
Santa Catarina (Muxagata and Montú 1999). In fact, the occurrence of this species is restricted to the coldest three months of the year. However, the absence of records of Evadne nordimanni, a typical species of the cold coastal waters of Argentina (Ramirez 1981) and the extreme south of Brazil (Resgalla Jr and Montú 1993), may indicate a significant alteration of the coastal branch of the Sub-Antarctic Water.

Finally, the species of the zooplankton community can be classified according to their preferential habits, as well as the physical-chemical characteristics of water masses occurring in Santa Catarina (Fig. 2 and Table IV). Many species present a wider distribution, and are abundant both in estuaries and beaches in the coastal 
TABLE IV

Zooplankton species by habitat and physical-chemical preferences of water occurrence.

\begin{tabular}{|c|c|c|}
\hline $\begin{array}{l}\text { Environment/ } \\
\text { Water Mass }\end{array}$ & Group & Species \\
\hline \multirow{4}{*}{ Beach } & Cladocera & Penilia avirostris; Pseudevadne tergestina \\
\hline & Copepoda & Acartia lilljeborgi; Oithona plumifera; Pseudodiaptomus richardi; Temora stylifera \\
\hline & Mysidacea & Metamysidopsis elongata atlantica \\
\hline & Chaetognatha & Sagitta enflata; Sagitta friderici \\
\hline \multirow{6}{*}{ Estuarine } & Cnidaria & Liriope tetraphylla \\
\hline & Cladocera & Penilia avirostris; Pseudevadne tergestina; Evadne spinifera; Pleopis polyphemoides \\
\hline & Copepoda & $\begin{array}{l}\text { Acartia lilljeborgi; Acartia tonsa; Calanopia americana; Euterpina acutifrons; Oithona oswaldocruzi; } \\
\text { Paracalanus quasimodo; Parvocalanus crassirostris; Pseudodiaptomus richardi; Temora stylifera; } \\
\text { Temora turbinata }\end{array}$ \\
\hline & Mysidacea & Metamysidopsis elongata atlântica \\
\hline & Chaetognatha & Sagitta enflata; Sagitta hispida; Sagitta friderici \\
\hline & Larvacea & Oikopleura dioica; Oikopleura parva \\
\hline \multirow{8}{*}{ Coastal } & Cnidaria & Liriope tetraphylla \\
\hline & Mollusca & Creseis virgula f. virgula; Janthina $s p$ \\
\hline & Cladocera & $\begin{array}{l}\text { Penilia avirostris; Pseudevadne tergestina; Evadne spinifera; Pleopis polyphemoides; } \\
\text { Podon intermedius; Pleopis schmackeri }\end{array}$ \\
\hline & Copepoda & $\begin{array}{l}\text { Acartia lilljeborgi; Centropages velificatus; Clytmnestra rostrata; Eucalanus pileatus; } \\
\text { Euterpina acutifrons; Hemycyclops thalassius; Labidocera fluviatilis; Macrosetella gracilis; Oithona } \\
\text { ovalis; Oithona plumifera; Oncaea venusta; Paracalanus quasimodo; Parvocalanus crassirostris; } \\
\text { Paracalanus nanus; Phaenna spinifera; Pseudodiaptomus richardi; Temora stylifera; Temora turbinata }\end{array}$ \\
\hline & Mysidacea & Promysis atlantica \\
\hline & Chaetognatha & Krohnitta pacifica; Sagitta enflata; Sagitta hispida; Sagitta friderici \\
\hline & Larvacea & Oikopleura dioica; Oikopleura parva \\
\hline & Thaliacea & Doliolum nationais; Thalia democratica; Weelia cylindrica \\
\hline \multirow{7}{*}{ Oceanic } & Cnidaria & Physalia physalis \\
\hline & Mollusca & $\begin{array}{l}\text { Creseis virgula f. virgula; Limacina inflata; Limacina trochiformis; Janthina sp; Atlanta sp.; Cavolinia } \\
\text { inflexa f. imitans }\end{array}$ \\
\hline & Cladocera & Penilia avirostris; Pseudevadne tergestina; Evadne spinifera \\
\hline & Copepoda & $\begin{array}{l}\text { Acartia negligens; Clytmnestra rostrata; Copilia mirabilis; Corycaeus speciosus; Farranulla gracilis; } \\
\text { Microsetella rosea; Phaenna spinifera; Rhincalanus nasutus; Sapphrina stellata }\end{array}$ \\
\hline & Chaetognatha & Sagitta serratodentata; Sagitta minima; Krohnitta pacifica \\
\hline & Larvacea & Tectillaria fertilis \\
\hline & Thaliacea & Doliolum nationalis; Thalia democratica; Thalia orientalis; Salpa fusiformis; Pyrosoma atlanticum \\
\hline \multirow{4}{*}{ Warm water } & Mollusca & Creseis virgula f. virgula \\
\hline & Cladocera & Penilia avirostris; Pseudevadne tergestina; Evadne spinifera \\
\hline & Copepoda & Acartia lilljeborgi; Oithona oswaldocruzi \\
\hline & Thaliacea & Doliolum nationais; Thalia democratica \\
\hline \multirow{2}{*}{ Cold water } & Cladocera & Pleopis polyphemoides; Podon intermedius \\
\hline & Copepoda & Acartia tonsa \\
\hline
\end{tabular}

region. Examples include A. lilljeborgi, P. quasimodo, T. tubinata and $S$. friderici, the oceanic species having more clearly defined distribution limits. However, the coastal species can be used as indicators of continental inputs in association with other more euryhalinas species, such as those of the Pseudodiaptomus and Paracalanus genera. Cold water species, which are observed in low densities in the samples despite being characterized as true indicators of water masses in the region, enable the occurrence of processes of upwelling and the influence of the Subtropical Shelf Front in the region during the winter months.

\section{CONCLUSIONS}

The zooplankton of the Santa Catarina coast has very similar characteristics to the fauna of environments of the southeast region of Brazil, where a prevalence of Tropical Shelf Water is observed (e.g. Creseis virgula f. 
virgula, Penilia avirostris; Acartia lilljeborgi and Oithona oswaldocruzi). However, it presents representatives of colder waters (e.g. Pleopis polyphemoides; Podon intermedius and Acartia tonsa) during the winter and spring, which are characterized by the presence of the Subtropical Shelf Front and by processes of upwelling or inflow of the SACW. These processes increase the diversity of indicator species of waters of different origins, and indicate that the coast is an area of transition between the tropical, subtropical and temperate faunas between the south and southeast regions of Brazil. However, the lack of information for the extreme south of the state points to the existence of a gap in knowledge and the small number of samplings around the area of upwelling of Santa Marta Cape.

\section{ACKNOWLEDGMENTS}

The author thanks the personnel of the Biological Oceanographic Laboratory, and the students, for their involvement in the area of planktology. In particular, thanks MSc. Oc. Ludmilla Dias Ad Vincula Veado for her participation and assistance in various analyses presented in this work. Also, the Conselho Nacional de Desenvolvimento Científico e Tecnológico (CNPq) for awarding the Research Grant, process 302165/2008-8.

\section{RESUMO}

Este trabalho apresentada informações oriundas de diferentes amostragens realizadas ao longo da costa de Santa Catarina com o objetivo de esboçar as características biogeográficas do zooplâncton assim como identificar espécies ou grupos de espécies com potencial uso como bioindicadores. A partir de um cheklist das espécies da comunidade zooplanctônica do estado observou-se que nos meses quentes do ano a fauna é similar aos dos estados do Paraná e São Paulo (e.g. Creseis virgula f. virgula, Penilia avirostris; Acartia lilljeborgi e Oithona oswaldocruzi), enquanto que nos meses frios, apresenta representantes costeiros da fauna do Rio Grande do Sul (e.g. Acartia tonsa). Entretanto, o zooplâncton é dominantemente termófilo na maior parte do ano, típico da Água Tropical de Plataforma. Existem diversas espécies do zooplâncton que podem ser utilizadas como indicadoras hidrológicas, permitindo diferenciar águas costeiras sob influência de aportes continentais (e.g. Paracalanus quasimodo e Parvocalanus crassirostris), comuns no norte do estado, e de processos de ressur- gências (e.g. Podon intermedius) e da influência da Frente do Prata originárias do sul (e.g. Pleopis polyphemoides). Os diferentes ambientes investigados apresentam uma abundância do zooplâncton dependente da influência de aportes continentais e da possibilidade de sua retenção e aproveitamento do enriquecimento costeiro que variam sazonalmente.

Palavras-chave: bioindicadores, cheklist, espécies costeiras, massas de água, ambientes costeiros, biogeografia.

\section{REFERENCES}

Bellotto VR, Kuroshima KN and Rörig LR. 1996. Relatório do Projeto Integrado da Foz do Rio Itajaí-Açú e Área Costeira Adjacente: diagnóstico e avaliação ambiental. Sub-Projeto: caracterização química da zona estuarina do Rio Itajaí-açú e área costeira adjacente. UNIVALI, Itajaí, $179 \mathrm{p}$.

BJÖRnBERG TSK. 1981. Copepoda. In: Boltvoskoy D (Ed), Atlas del zooplancton del atlántico sudocidental y métodos de trabajo con el zooplancton marino. Publ Esp INIDEP, Mar del Plata, Argentina, p. 587-680.

Boltovskoy D. 1981. Atlas del zooplancton del Atlántico Sudoccidental y métodos de trabajo con el zooplancton marino. Publ Esp INIDEP, Mar del Plata, 936 p.

Boltovskoy D. 1999. South Atlantic Zooplankton. Backhuys Publ, Leiden. Volumes 1 e 2, 1706 p.

Brandini FP, LOPES RM, GutSEIT KS, SPACH HL AND SASSI R. 1997. Planctonologia na plataforma continental do Brasil. Diagnose e revisão bibliográfica. REVIZEE, $196 \mathrm{p}$.

CAmpos MAG. 2004. Apendiculárias da costa brasileira. Tese de Doutorado, Instituto Oceanográfica, USP, 169 p.

Carvalho JLB, Schettini CAF And Ribas TM. 1998. Estrutura termohalina do litoral centro-norte catarinense. Notas Tec FACIMAR 2: 181-197.

Cunha SR, Nascimento J, Lima GB, Zacharjasiewicz G, Crestani DEV, Mafra Jr Ll, Pazeto FD, SAnT'AnA F And Costa CSB. 1999. Distribuição e biomassa de macroalgas em um manguezal da Baía da Babitonga, SC: Resultados Preliminares. Notas Tec Facimar 3: 1-15.

DUARTE AK. 1999. Ocorrência de monstrilloida (Copépodo) em águas costeiras do sul do Brasil. Nauplius 7: 201-202.

Hille E, Schettini CAF ANd Ribeiro MR. 2008. Estrutura termohalina no litoral de Santa Catarina nos anos de 2005 e 2006. In: BRAGA ES (Ed). Oceanografia e mudanças globais. São Paulo, Edusp, p. 371-381. 
Knoppers BA, Opitz SS, Souza MP ANd Miguez CF. 1984. The spatial distribution of particulate organic matter and some physical and chemical water properties in Conceição Lagoon, Santa Catarina, Brazil (July 19, 1982). Arqu Biol Tecnol 27(1): 59-77.

KoettKer AG AND Freire AS. 2006. Spatial and temporal distribution of decapod larvae in the subtropical waters of the Arvoredo archipelago, SC, Brazil. Iheringia, Ser Zool 96(1): 31-39.

Kuroshima KN And Bellotto VR. 1998. Caracterização química da coluna d'água da Baía da Babitonga. In: Rodrigues VAB (Ed), Proteção e Controle de Ecossistemas Costeiros: Manguezal da Baía da Babitonga. Brasília, Brasil: IBAMA, p. 75-84.

LOPES RM. 2007. Marine zooplankton studies in Brazil A brief evaluation and perspectives. An Acad Bras Cienc 79: 369-379.

Lopes RM, Katsuragawa M, Dias JF, Montú MA, Muelbert JH, GorRi C AND BRANDini FP. 2006. Zooplankton and ichthyoplankton distribution on the southern Brazilian shelf: an overview. Sci Mar 70(2): 189-202.

Macedo-SoAres LCP, Birolo AB And Freire AS. 2009. Spatial and temporal distribution of fish eggs and larvae in a subtropical coastal lagoon, Santa Catarina State, Brazil. Neotropical Ichthyology 7(2): 231-240.

Miranda LD. 1982. Análise de massa de água de plataforma continental e da região oceânica adjacente: Cabo de São Tomé (RJ) à ilha de São Sebastião (SP). Tese de Livre Docência, Universidade de São Paulo, 123 p.

MonTú M. 1980. Zooplâncton do estuário da Lagoa dos Patos. I. Estrutura e variações temporais e espaciais da comunidade. Atlântica 4: 53-72.

Montú M. 1987. Síntese dos Conhecimentos sobre Zooplâncton Estuarino. Simpósio sobre Ecossistemas da Costa Sul e Sudeste Brasileira: Síntese dos Conhecimentos em Cananéia. Cananéia 3: 176-196.

Montú M AND CORDEIRO AT. 1988. Zooplâncton del complejo estuarial de la Bahía de Paranaguá. I. Composición, dinámica de las especies, ritmos reproductivos y acción de los factores ambientales sobre la comunidad. Nerítica 3(1): 61-83.

Montú M And Gloeden IM. 1986. Atlas dos cladocera e copepoda (Crustacea) do estuário da Lagoa dos Patos (Rio Grande, Brasil). Nerítica, Pontal do Sul, PR 1(2): $1-134$.

MuXagata E And Montú MA. 1999. Os cladoceros da plataforma continetal sudeste brasileira: Distribuição, densidade e biomassa (Inverno de 1995). Nauplius 7: 151-172.

ODEBRECHT C. 1988. Variações espaciais e sazonais do fitoplâncton, protozooplâncton e metazooplâncton na Lagoa da Conceição, Ilha de Santa Catarina. Brasil. Atlântica 10(1): 21-40.

OMORI M AND IKEDA T. 1984. Methods on marine zooplankton ecology. J Wiley \& Sons, New York, 332 p.

PAFFenhoefer GA AND STEARns DE. 1988. Why is Acartia tonsa (Copepoda: Calanoida) restricted to nearshore environments? Mar Ecol Prog Series 42: 33-38.

Parsons TR, TAKahashi M And Hargave B. 1984. Biological Oceanographic Processes. Pergamon Press, Oxford, $330 \mathrm{p}$.

Piola AR, Campos EJD, Möller Jr OO, Charo M AND Martinez C. 2000. Subtropical shelf front off eastern south America. J Geoph Res 105(C3): 65656578.

Piola AR, Matano RP, Palma E, Möller Jr OO AND CAmpos EJD. 2005. The influence of the Plata river discharge on the western South Atlantic Shelf. Geoph Res Letters 32: 1-4.

Pires-VAnin AMS, Rossi-Wongtschowski CLDB, Aidar E, Mesquita HSL, Soares LSH, KatsuraGAWA M AND MATSUURA Y. 1993. Estrutura e função do ecossistema da plataforma continental do Atlântico sul brasileiro: síntese dos resultados. In: PIRES-VANIN AMS (Ed), Estrutura e função do ecossistema de plataforma continental do Atlântico Sul Brasileiro. Publ Esp do IOUSP 10: 217-231.

RAmirez FC. 1981. Cladocera. In: Boltovskoy D (Ed). Atlas del zooplankton do Atlantico sudoccidental y metodos de trabajo con el zooplankton marino. Publ. Esp. INIDEP, Mar del Plata, Argentina, p. 533-542.

RESGALLA JR C. 2001. Estudo de impacto ambiental sobre a comunidade do zooplâncton na enseada do saco do Limões, baía sul da ilha de Santa Catarina, Brasil. Atlântica 23: 5-16.

Resgalla Jr C, Carvalho Jl, Pereira FOJ, Rörig LR, Rodrigues-Ribeiro M, TAMANAHA MS AND ProEnÇA LAO. 2004. Migração vertical e taxas fisiológicas de Thalia democratica (Salpidea: Thaliacea) na reserva marinha do Arvoredo, Santa Catarina. Notas Tec FACIMAR 8: 45-54.

Resgalla Jr C, Coutinho de Souza VG, Rörig LR AND SCHETTINI CAF. 2008. Spatial and temporal variation of the zooplankton community in the area of influ- 
ence of the Itajaí-Açu river, SC (Brazil). Braz J Oceanogr 56(3): 211-224.

Resgalla Jr C, De la Rocha C ANd Montú M. 2001. The influence of Ekman transport on zooplankton biomass variability off southern Brazil. J Plankton Res 23(1): 1191-1216.

Resgalla Jr C, GonçAlves VC AND Klein AHF. 2005. The occurrence of jellyfish stings on the Santa Catarina coast, southern Brazil. Braz J Oceanogr 53(3-4): 183186.

Resgalla JR C And Montú M. 1993. Cladóceros marinhos da plataforma continetal do Rio Grande do Sul Brasil. Nauplius 1: 63-79.

Resgalla JR C And Montú M. 1995. Quetognatos de la plataforma continental del sur de Brasil. Investig Marinas 10(1-2): 23-41.

Resgalla Jr C And Schettini CAF. 2006. Características e variação do seston da enseada da Armação do Itapocoroy, Penha, SC. In: BRANCO JO AND MARENZI AWC (Eds), Bases ecológicas para um desenvolvimento sustentável: estudo de caso em Penha, SC. Editora Univali, p. 107-120.

Resgalla JR C AND Veado LDA. 2006. Zooplâncton da enseada da Armação do Itapocoroy, Penha, SC. In: Branco JO AND MAREnZI AWC (Eds), Bases ecológicas para um desenvolvimento sustentável: estudo de caso em Penha, SC. Editora Univali, p. 121-132.

Rocha RM, Moreno TR AND Metri R. 2005. Ascídias (Tunicata, Ascidiacea) da reserva biológica marinha do Arvoredo, Santa Catarina, Brasil. Rev Bras Zoo 22(2): $461-476$.

RöRIG LR. 2005. Uso múltiplos e qualidade das águas da bacia do baixo Itajaí-Açu, SC. Elementos para um gerenciamento integrado. Tese de Doutorado. Ecologia e Recursos Naturais, UFSCar, 295 p.

Rörig LR, Resgalla Jr C, Pezzuto PR, Alves E AND Morelli F. 1997. Análise ecológica de um processo de acumulação da diatomácea Anaulus sp na zona de arrebentação da praia de Navegantes (Santa Catarina, Brasil). In: ABsAlão RS AND Esteves AM (Eds). Oecologia Brasiliensis, 3: Ecologia de praias arenosas do litoral brasileiro, p. 29-43.

Rörig LR, ResGalla JR C AND SChettini CAF. 2003. Estrutura da assembléia planctônica através do estuário e da pluma do rio Itajaí-Açu. Rev Estudos Ambientais 5(1): 76-94.

Rossetto Al, Mora JM, Correa PR, Resgalla Jr C, Proença LAO, LANG da Silveira F AND Haddad
JR V. 2007. Prurido do traje de banho: relato de seis casos no Sul do Brasil. Rev Soc Bras Med Trop 40(1): 78-81.

SChetTini CAF AND CARVAlHo JLB. 1998. Hidrodinâmica e distribuição de sedimentos em suspensão dos estuários dos rios Itapocu, Tijucas e Camboriú (Relatório). Notas Tec FACIMAR 2: 141-153.

Schettini CAF, Carvalho JLB and Truccolo EC. 1999. Aspectos hidrodinâmicos da enseada da Armação de Itapocoroy, SC. Notas Tec Facimar 3: 99-109.

Schettini CAF, Kuroshima KN, Pereira Filho J, RÖRIG LR AND RESGALla JR C. 1998. Oceanographic and ecological aspects of the Itajaí-Açu river plume during a high discharge period. An Acad Bras Cienc 70: $335-351$.

Schettini CAF, Resgalla Jr C, Pereira Filho J, Silva MAC, Truccolo EC ANd Rörig LR. 2005. Variabilidade temporal das características oceanográficas e ecológicas da região de influência fluvial do rio ItajaíAçu. Braz J Aquat Sci Technol 9(2): 93-102.

Schettini CAF, Truccolo EC, Resgalla JR C, Rörig LR AND KUROSHIMA KN. 2002. O sistema estuarino da baía da Babitonga. In: KNIE JLW (Ed), Atlas ambiental da região de Joinville - Complexo hídrico da baía da Babitonga, p. 113-118.

Severino A And Resgalla JR C. 2005. Descrição dos estágios larvais de Megabalanus coccopoma (Darwin, 1854) e sua variação temporal na enseada de Itapocoroy (Santa Catarina, Brasil). Atlântica 27(1): 5-16.

SouZA-CONCEIÇÃo JM. 2008. Praias estuarinas como habitat de criação para estágios iniciais de peixes na Ilha de São Francisco do Sul (Baía da Babitonga, Santa Catarina). Tese de doutorado. Universidade Federal do Paraná, 198 p.

VALENTIN JL. 1988. A dinâmica do plâncton da ressurgência de Cabo Frio - RJ. In: Brandini FP (Ed), Mem. III Encontro Brasileiro de Plâncton. Caiobá, p. 25-35.

Valentin JL, Gaeta AS, Sapch HL, Montú M And OdeBrecht C. 1994. Diagnóstico ambiental oceânico e costeiro das regiões sul e sudeste do Brasil. Volume 4. Oceanografia Biológica: Plâncton. Brasília, Petrobras, $321 \mathrm{p}$.

VEAdo LDV AND RESGALla JR C. 2005. Alteração da comunidade zooplanctônica do saco dos Limões após impacto das obras da via expressa sul - Baía Sul da Ilha de Santa Catarina. Braz J Aquatic Sci Technol 9(2): 65-73. 